\title{
Spinal Opioid Analgesia: How Critical Is the Regulation of Substance P Signaling?
}

\author{
Jodie A. Trafton, ${ }^{1}$ Catherine Abbadie,, ${ }^{1}$ Serge Marchand, ${ }^{2}$ Patrick W. Mantyh, ${ }^{3}$ and Allan I. Basbaum ${ }^{1}$ \\ ${ }^{1}$ Departments of Anatomy and Physiology and W. M. Keck Foundation for Integrative Neuroscience, University of \\ California San Francisco, San Francisco, California 94143, 2Department of Clinical Sciences, University of Quebec, \\ Rouyn-Noranda, Quebec, Canada, J9X5E4, and ${ }^{3}$ Molecular Neurobiology Laboratory, Veterans Administration Medical \\ Center, Minneapolis, Minnesota 55417
}

\begin{abstract}
Although opioids can reduce stimulus-evoked efflux of Substance $\mathrm{P}(\mathrm{SP})$ from nociceptive primary afferents, the consequences of this reduction on spinal cord nociceptive processing has not been studied. Rather than assaying SP release, in the present study we examined the effect of opioids on two postsynaptic measures of SP release, Fos expression and neurokinin-1 (NK-1) receptor internalization, in the rat. The functional significance of the latter was first established in in vitro studies that showed that $\mathrm{SP}$-induced $\mathrm{Ca}^{2+}$ mobilization is highly correlated with the magnitude of SP-induced NK-1 receptor internalization in dorsal horn neurons. Using an in vivo analysis, we found that morphine had little effect on noxious stimulus-evoked internalization of the NK-1 receptor in lamina I
\end{abstract}

neurons. However, internalization was reduced when we coadministered morphine with a dose of an NK-1 receptor antagonist that by itself was without effect. Thus, although opioids may modulate SP release, the residual release is sufficient to exert maximal effects on the target NK-1 receptors. Morphine significantly reduced noxious stimulus-induced Fos expression in lamina I, but the Fos inhibition was less pronounced in neurons that expressed the NK-1 receptor. Taken together, these results suggest that opioid analgesia predominantly involves postsynaptic inhibitory mechanisms and/or presynaptic control of non-SP-containing primary afferent nociceptors.

Key words: morphine; dorsal horn; tachykinin; nociception; internalization; intrathecal
Although spinal administration of opioids produces a profound antinociceptive effect, the mechanisms underlying this action are not fully understood. Because there is considerable evidence that primary afferent-derived Substance P (SP) contributes to the transmission of nociceptive messages in the spinal cord (Hökfelt et al., 1975; Hylden and Wilcox, 1981; Duggan et al., 1988; DeKoninck and Henry, 1991) and because opioid receptors are located on primary afferents, many studies have focused on the ability of opioids to presynaptically control SP release. In fact, opioids reduce $\mathrm{K}^{+}$or noxious stimulus-evoked release of SP (Jessell and Iversen, 1977; Yaksh et al., 1980; Hirota et al., 1985; Aimone and Yaksh, 1989), leading to the hypothesis that inhibition of SP release by opioids is a major mechanism by which opioids produce analgesia. However, none of these studies have demonstrated functional consequences of this reduction in SP release. In the present study, we specifically examined the functional impact of such presynaptic inhibitory controls on SPmediated signaling in the spinal cord dorsal horn.

SP binds preferentially to the NK-1 receptor, a G-proteincoupled receptor that is expressed in the spinal cord dorsal horn (Brown et al., 1995). Because the NK-1 receptor internalizes when it binds agonist (Bunnett et al., 1995), we have used NK-1

Received May 26, 1999; revised Aug. 17, 1999; accepted Aug. 19, 1999.

This research was supported by National Institutes of Health Grants DE 08973, NS 14627, and NS 21445. C.A. was supported by Institut National de la Santé et de la Recherche Médicale, France, and Institut UPSA de la douleur. J.T was supported in part by a National Science Foundation Predoctoral fellowship.

Correspondence should be addressed to Allan I. Basbaum, Department of Anatomy, University of California San Francisco, Box 0452, San Francisco, CA 941430452. E-mail: aib@phy.ucsf.edu.

Dr. Abbadie's present address: Cotzias Laboratory of Neuro-Oncology, Memorial Sloan-Kettering Cancer Center, New York, NY 10021.

Copyright @ 1999 Society for Neuroscience 0270-6474/99/199642-12\$05.00/0 receptor internalization as a marker of neurons that are activated by SP. We demonstrated that intense noxious peripheral stimulation induces internalization of the NK-1 receptor in lamina I neurons (Mantyh et al., 1995; Abbadie et al., 1997). During inflammation, NK-1 receptor-positive neurons located more ventrally, in laminae III-VI, also internalize the NK-1 receptor in response to noxious stimulation (Abbadie et al., 1997). This technique thus provides a simple and reliable method for visualizing signaling produced by SP.

Our aim, therefore, was to gauge the effects of opioid receptor agonists on the functional consequences of noxious stimulationinduced release of substance $P$ from primary afferent nociceptors. Because studies have reported a greater potency of morphine during inflammatory injury (Colpaert, 1979; Kayser and Guilbaud, 1983), we examined the effects of morphine both in normal rats and in rats with persistent hindpaw inflammation. To ensure that the end point of internalization indeed correlates with NK-1 receptor-mediated signaling, we performed in vitro studies in which we compared SP-mediated increases in intracellular calcium and NK-1 receptor internalization. Because opioids likely have other effects on neurotransmitter release and interneuronal signaling in the spinal cord, we also evaluated the effect of morphine on a more general marker of neuronal activity, namely Fos expression, in dorsal horn neurons that express the NK-1 receptor. Finally, to discriminate between presynaptic and postsynaptic opioid effects, we measured the effect of morphine on NK-1 receptor internalization and Fos expression produced by direct intrathecal (i.t.) injection of SP.

\section{MATERIALS AND METHODS}

Experimental animals. All experiments were reviewed and approved by the Institutional Care and Animal Use Committee at University of 
California San Francisco (UCSF). Experiments were performed on male Sprague Dawley rats (Bantin and Kingman, Fremont, CA), weighing 230-270 gm. In some rats, inflammation was induced by subcutaneous injection of $100 \mu \mathrm{l}$ of complete Freund's adjuvant (CFA; killed mycobacterium butyricum suspended in mineral oil, solution at $10 \mathrm{mg} / \mathrm{ml}$; Sigma, St. Louis, MO) in the left hindpaw. Rats were stimulated $2 \mathrm{~d}$ after the inflammation was induced.

Drug treatments. Morphine sulfate was given subcutaneously $(10 \mathrm{mg} /$ $\mathrm{kg}$ ) at the base of the neck 25-30 min or intrathecally (10 or 30 $\mu \mathrm{g}$ ) 20-25 min before stimulation. Selective opioid receptor agonists were given intrathecally $20 \mathrm{~min}$ before stimulation: [D-Ala ${ }^{2}, N-\mathrm{Me}^{-\mathrm{Phe}^{4}}$, Gly $\mathrm{Gl}^{5}$-01]enkephalin (DAMGO) (1.0 $\mu \mathrm{g}$, Sigma), [D-Pen ${ }^{2,5}$-enkephalin (DPDPE) (30 $\mu \mathrm{g}$, Sigma), or U-50488H (100 $\mu \mathrm{g}$, RBI, Natick, MA). The doses of these opioids were chosen because they are established antinociceptive doses (Miaskowski et al., 1991). GR 205171A dihydrochloride salt, an NK-1 receptor antagonist (kindly provided by Glaxo-Wellcome, Stevenage, Hertfordshire, UK) was given subcutaneously (1.0 or 10 $\mathrm{mg} / \mathrm{kg}$ ) at the base of the neck, 20-25 min before the stimulation. In control experiments, we established that neither saline nor any of these drugs induced internalization of the NK-1 receptor without additional stimulation (see Fig. 1). Subcutaneous injections were made in a $1.0 \mathrm{ml}$ volume of saline. Intrathecal injections, performed under halothane anesthesia, were made directly between the S1 and S2 vertebrae with a 30 gauge needle in a $20 \mu \mathrm{l}$ volume of saline. Control animals received an equal volume of saline. In some experiments, naloxone $(1.0 \mathrm{mg} / \mathrm{kg}$, s.c.) was given 5 min before the morphine.

To assess the possible postsynaptic effects of morphine on neurons that express the NK-1 receptor, we injected SP intrathecally (100 $\mu \mathrm{g}$, diluted in $20 \mu \mathrm{l}$ of saline, Sigma). This dose induces internalization of the NK-1 receptor in $100 \%$ of neurons in the lumbar cord. In these studies we injected morphine ( $10 \mu \mathrm{g}$, i.t., or $10 \mathrm{mg} / \mathrm{kg}$, s.c.) $20-25 \mathrm{~min}$ before the SP injections.

Hindpaw stimulation. All experiments were performed $10-15$ min after the rats were anesthetized with sodium pentobarbital $(50 \mathrm{mg} / \mathrm{kg}$, i.p.). This dose blocked flexor reflex responses to hindpaw stimulation. Noxious mechanical stimulation (pinch) was applied to the distal part of one hindpaw with a hemostat for $15 \mathrm{sec}$. For thermal stimulation, the rat's hindpaw (to just below the ankle) was dipped for 2 min into a water bath heated to $50^{\circ} \mathrm{C}$. To study noxious stimulus-induced internalization of the $\mathrm{NK}-1$ receptor, the rats were perfused $5 \mathrm{~min}$ after the stimulation ended. For experiments that examined double labeling of NK-1 receptor and Fos, the rats were perfused $90 \mathrm{~min}$ after the stimulation.

Immunocytochemistry. At the appropriate time, the animals received an additional injection of sodium pentobarbital $(100 \mathrm{mg} / \mathrm{kg}$, i.p.) and were perfused intracardially with $50 \mathrm{ml}$ of $0.1 \mathrm{M}$ PBS followed by $500 \mathrm{ml}$ of $10 \%$ formalin in $0.1 \mathrm{M}$ phosphate buffer (PB). After the perfusion, the lumbar spinal cord was removed, post-fixed for $4 \mathrm{hr}$ in the same fixative, and then cryoprotected overnight in $30 \%$ sucrose in $0.1 \mathrm{M}$ PB. Immunostaining was performed on $30 \mu \mathrm{m}$ lumbar spinal cord sections (from L2 to L6 segments) cut in the sagittal plane on a freezing microtome. The tissue sections were incubated for $30 \mathrm{~min}$ at room temperature in a blocking solution of $3 \%$ normal goat serum in PBS with $0.3 \%$ Triton-X (NGST).

For immunofluorescent staining of the NK-1 receptor, the sections were incubated overnight in the primary antiserum, diluted to 1:5000. The characteristics of the antiserum, directed against the C-terminal tail of the NK-1 receptor, have been described previously (Vigna et al., 1994). After the primary antiserum, the sections were washed three times in $1 \%$ NGST and then incubated in indocarbocyanine Cy-3-conjugated goat anti-rabbit IgG (Jackson ImmunoResearch, West Grove, PA) (1: $600)$ for $2 \mathrm{hr}$ at room temperature. For double-labeling studies, sections were first incubated in the Fos antisera (1:30,000; kindly given by Dr. Dennis Slamon, University of California Los Angeles) overnight. Immunostaining was performed according to the avidin-biotin peroxidase method of Hsu et al. (1981). To localize the HRP immunoreaction product for Fos, we used a nickel-intensified diaminobenzidine protocol with glucose oxidase. Sections were then incubated in the NK-1 receptor antisera $(1: 20,000)$, and a diaminobenzidine protocol with glucose oxidase without nickel was used. Finally, the sections were washed three times in PB, mounted on gelatin-coated slides, dried, and coverslipped with DPX (Electron Microscopy Science, Gibbstown, NJ).

Quantification of immunoreactivity and statistical analysis. Quantification of NK-1 receptor internalization was performed as previously described (Abbadie et al., 1997). Briefly, to analyze internalization in cell bodies we used a $20 \times$ objective on a Nikon FXA microscope equipped for fluorescence. We counted NK-1 receptor-like immunoreactive cell bodies in laminae I, III-IV, and V-VI of the dorsal horn, ipsilateral to the side of stimulation, from segments L2 to L6. NK1 receptor-like immunoreactivity is uniformly distributed on the surface of cell bodies that do not contain internalized receptors, but in the neurons that have internalized NK-1 receptors, the cytoplasm contains bright, immunofluorescent endosomes (see Fig. 1). Neurons were considered internalized if they contained $>20$ endosomes in the cell body. All counts are expressed as the percentage of NK-1 receptor-immunoreactive neurons that contain internalized receptor.

Because we found no difference in the magnitude of internalization along the mediolateral extent of the superficial dorsal horn, we counted all of the neurons within a section, without taking into account the mediolateral position of the cells. Neurons from five sagittal sections were counted from each rat for both NK-1 receptor internalization and Fos double labeling.

To analyze double labeling for Fos and the NK-1 receptor, we only counted neurons in lamina I. We recorded the number of neurons that were (1) only positive for Fos, (2) only positive for the NK-1 receptor, and (3) double-labeled for both NK-1 receptor and Fos. In all experiments, the investigators who quantified internalization or double labeling were not aware of the treatment that the animal received. For statistical analysis, we used a two-way ANOVA for treatment condition (saline versus drug) and for spinal segment (L2-L6 lumbar segments). For comparisons between treatment conditions at a given spinal segment (performed only when there was an overall effect of treatment), we used Fisher's PSLD test; $p<0.05$ was considered statistically significant and was denoted with a star in the figures.

Confocal images. Although most quantitative analysis was performed on tissue observed with epi-illuminated fluorescence, to demonstrate that morphine did not cause a decrease in the number of endosomes in each individual neuron, we examined some sections by confocal microscopy. The confocal images described below (see Fig. 1) were collected with an MRC 600 confocal microscope (Bio-Rad, Hercules, CA) with a $60 \times$ objective. Images were reformatted in NIH-Image (version 1.60), and montages were created in Photoshop (Adobe, version 3.0). Optical sections of $\sim 1.0 \mu \mathrm{m}$ were taken through the center of 20 neurons in lamina I of the L4 segment for each animal. The first five neurons found on each of four sections were imaged. Bright puncta within the limits of the cell body were counted as endosomes. The investigator taking images and counting endosomes was unaware of the treatment of the animal.

\section{Spinal cord cultures}

Spinal cord cultures were prepared from embryonic day 19 Sprague Dawley rats using a modification of the method of Yu et al. (1984). Spinal cords were dissected out, washed, and treated with a standard $0.25 \%$ trypsin/versene mixture (cell culture facility, UCSF) for $12 \mathrm{~min}$. The cords were again washed and mechanically dissociated with a large-bore pipette. Cells from each cord were diluted into $24 \mathrm{ml}$ of MEM-PAK buffer (cell culture facility, UCSF) supplemented to contain 5\% normal horse serum, 5\% fetal calf serum and penicillin/streptomycin, $30 \mathrm{~mm}$ glucose, and $2 \mathrm{~mm}$ glycine. Cells were plated on glass coverslips (Carolina, Burlington, NC) or 8-well coverglass (Fisher, Santa Clara, CA) and incubated at $37^{\circ} \mathrm{C}$ in a humidified incubator with $5 \% \quad \mathrm{CO}_{2} / 95 \% \quad \mathrm{O}_{2}$. Cultures were used at 5-6 d of age.

Calcium imaging. Spinal cord cultures plated on 8-well coverglass were incubated in calcium imaging buffer containing (in $\mathrm{mM}$ ): $130 \mathrm{NaCl}, 0.3$ $\mathrm{KCl}, 2.5 \mathrm{CaCl}_{2}, 0.6 \mathrm{MgCl}_{2}, 1.2 \mathrm{NaHCO}_{3}, 10$ glucose, 10 HEPES, pH 7.4, containing $\mu \mathrm{M}$ fura- $2 \mathrm{AM}$ and $0.02 \%$ pleuronic acid (Molecular Probes, Eugene, OR) for $25 \mathrm{~min}$. The fura-2 AM was then removed and replaced with $150 \mu \mathrm{l}$ per well of fresh CI buffer. Ratiometric calcium imaging was performed with a Nikon Diaphot fluorescence microscope equipped with a variable filter wheel (Sutter Instruments, Novato, CA) and an intensified CCD camera (Hamamatsu, Bridgewater, NJ). Dual images (340 and $380 \mathrm{~nm}$ excitation, $510 \mathrm{~nm}$ emission) were collected every $4 \mathrm{sec}$. For each well, five baseline images were recorded, and then $150 \mu \mathrm{l}$ of SP in CI buffer at twice the desired final concentration was pipetted into the well. Responses were recorded for the following $40 \mathrm{sec}$.

For every image that was collected, we calculated the average 340/380 ratio for each of the cells in the field. All cells that showed an average increase of the $340 / 380$ ratio that was greater than twice the average baseline 340/380 ratio for that cell were considered responders. Only responders were considered in the subsequent analysis. In each well, we calculated the total increase in intracellular calcium for all responders in each well by taking the sum of the 340/380 ratios over the $40 \mathrm{sec}$ after SP 

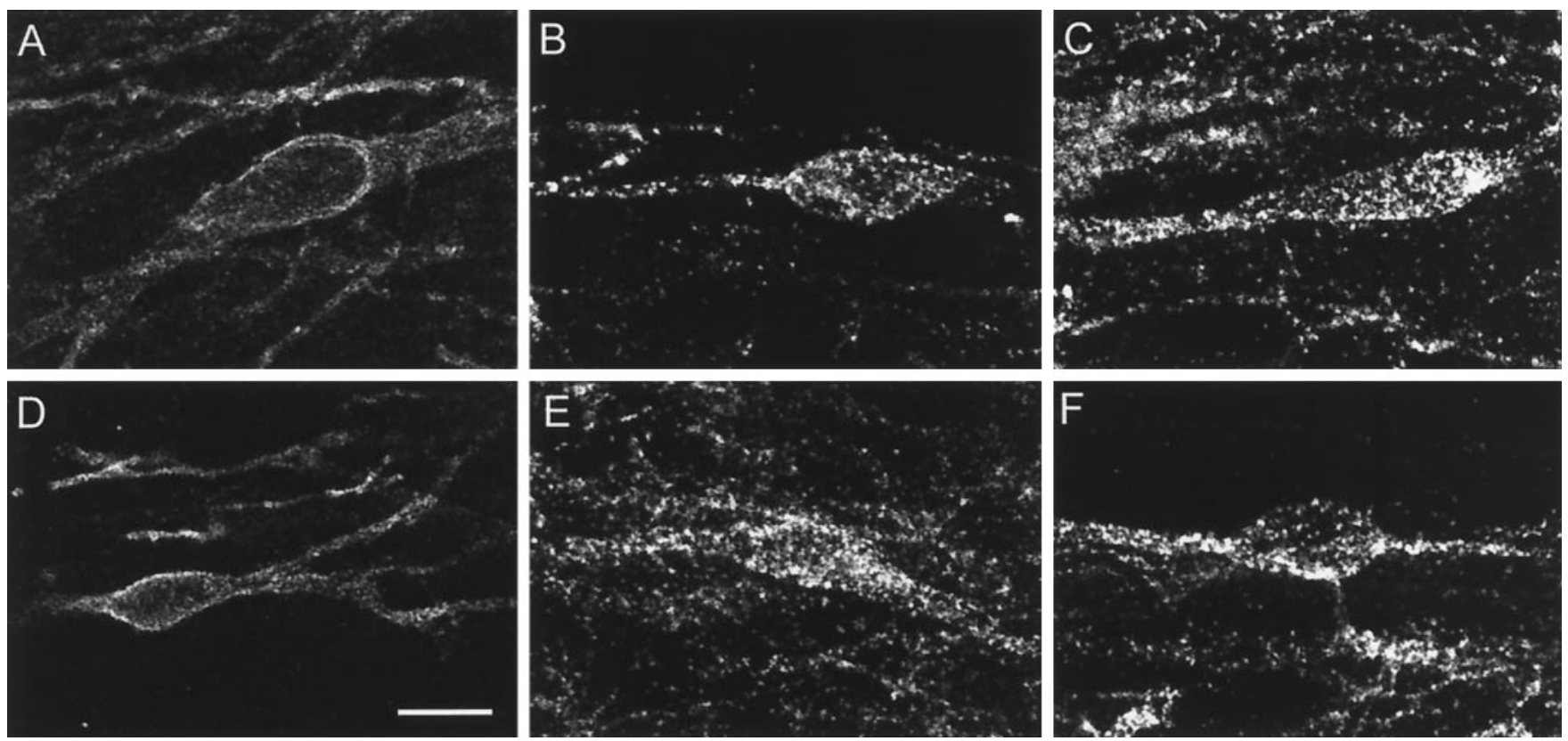

Figure 1. These confocal images $(A-F)$ illustrate the effect of morphine on noxious stimulus-evoked internalization of the NK-1 receptor in NK-1 receptor-immunoreactive neurons. Each panel is from sagittal sections through lamina I of the L4 segment of the spinal cord. The confocal images were taken through the center of neurons that express the NK-1 receptor. In all examples, the noxious stimulus was a 15 sec pinch of the hindpaw. $A-C$, Saline pretreatment; $D-F$, morphine pretreatment. $A$, Contralateral to the noxious stimulus in a rat that received intrathecal saline. The NK-1 receptor-LI is localized to the plasma membrane, indicating that internalization had not occurred. $D$, Contralateral to the noxious stimulus in a rat that received intrathecal morphine. There is no NK-1 receptor internalization. By contrast, in $B, C, E$, and $F$, there is extensive NK-1 receptor-LI in endosomes in the cytoplasm, indicating extensive internalization. $B$, Ipsilateral in a rat that received intrathecal saline; $C$, ipsilateral in a rat that received subcutaneous saline; $E$, ipsilateral in a rat that received intrathecal morphine $(30 \mu \mathrm{g}) ; F$, ipsilateral in a rat that received subcutaneous morphine $(10 \mathrm{mg} / \mathrm{kg})$. Note that the magnitude of NK-1 receptor internalization in individual cells (number or brightness of endosomes) was not altered by morphine treatment. Scale bar (shown in $D$ ): $20 \mu \mathrm{m}$.

application (10 images). From each value we subtracted the average baseline $340 / 380$ ratio of the cell, which was measured over the $20 \mathrm{sec}$ before application of SP.

In vitro internalization. Spinal cord cultures plated on coverglass were incubated in culture media containing SP. After 15 min, media was removed, and cells were fixed in 10\% formalin for $20 \mathrm{~min}$. NK-1 receptor was labeled for immunofluorescent analysis as described above for the tissue sections. Confocal images $(75 \times 4.0$ iris diameter) were taken of five NK-1 receptor-positive neurons per coverslip, and the number of endosomes in each cell was counted and averaged for neurons over the coverslip. Images were taken on a Bio-Rad MRC 1024 confocal microscope. The investigator taking images and counting endosomes was unaware of the treatment that the cultures received. All neurons with $>10$ endosomes in their cytoplasm were considered responders.

Statistical analysis. To normalize the responses of the neurons, we first determined the maximal response to SP and then determined the percentage of this response generated by different doses of SP. Percent maximal possible effect (MPE) produced by a given dose was calculated as follows: percent MPE $=(($ average response produced by the particular SP dose) - (average response produced in the absence of SP))/ (average maximal effect) $\times 100$.

We also assessed the response after correcting for the fact that not all neurons in a given dish will respond (because not all express the NK-1 receptor). For this calculation we first determined the maximal number of responsive cells (responders) and then determined the percentage of this response generated by different doses of SP. Percent MPR produced by a given dose was calculated as follows: percent MPR $=(($ average percent of responders produced by the particular dose of SP) - (average percent of responders produced in the absence of SP))/(average maximal percent responders) $\times 100$.

The thresholds for considering a cell a responder were chosen arbitrarily on the basis of variation observed in untreated cultures. Analysis was also performed using 15 endosomes and 1.5 times baseline as thresholds. The two approaches produced similar results. $\mathrm{EC}_{50}$ values were calculated with Prism (GraphPad Software). For statistical analysis, we used a two-way ANOVA for measure (intracellular calcium concentration or NK-1 receptor internalization) and for SP dose.

\section{RESULTS}

As we reported previously (Brown et al., 1995), there is a very distinct pattern of NK-1 receptor staining in the dorsal horn of the rat. The densest staining is found in cell bodies and dendrites of lamina I. The immunoreactivity is best viewed in sagittal section because the dendrites, which express the bulk of the immunoreaction product, arborize in the rostrocaudal plane. Lamina II (the substantia gelatinosa) contains very little NK-1 receptor-like-immunoreactivity (LI), except for dorsally directed dendrites of relatively large NK-1 receptor-LI neurons located in laminae III-IV. Smaller neurons with round cell bodies are also located in laminae III-VI; dendrites of these neurons arborize in all directions and in all planes. Although dendrites of the majority of lamina $\mathrm{V}$ neurons that express the NK-1 receptor arborize locally, a few also have dorsally directed dendrites that extend into lamina I. Finally, densely stained, large, round cell bodies are clustered around the central canal. In all regions, the NK-1 receptor immunoreactivity is concentrated on the plasma membrane of cell bodies and dendrites (Fig. 1 $A, D$ ).

\section{Effects of opioids on internalization of the NK-1 receptor induced by peripheral stimulation}

\section{Systemic morphine}

As we previously reported (Abbadie et al., 1997), noxious mechanical stimulation of the hindpaw (pinch) is a particularly effective stimulus for evoking NK-1 receptor internalization in dorsal horn neurons. In the present study we used a $15 \mathrm{sec}$ stimulus, which induces internalization in $80-100 \%$ of $\mathrm{NK}-1$ receptor immunoreactive lamina I neurons in the L4 segment of normal rats. The percentage of neurons that internalized the 


\section{Mechanical Stimulation}

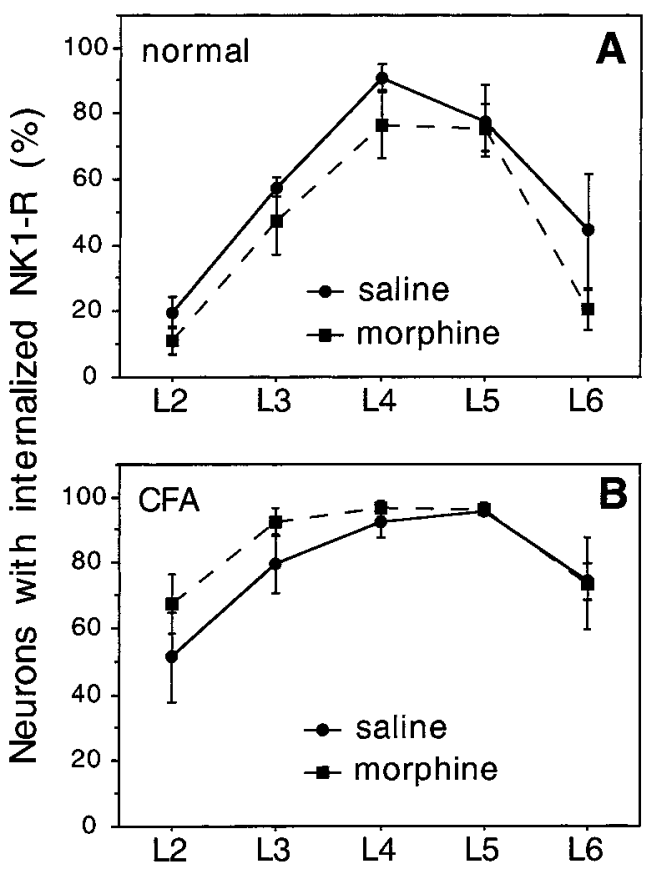

Thermal St imulation
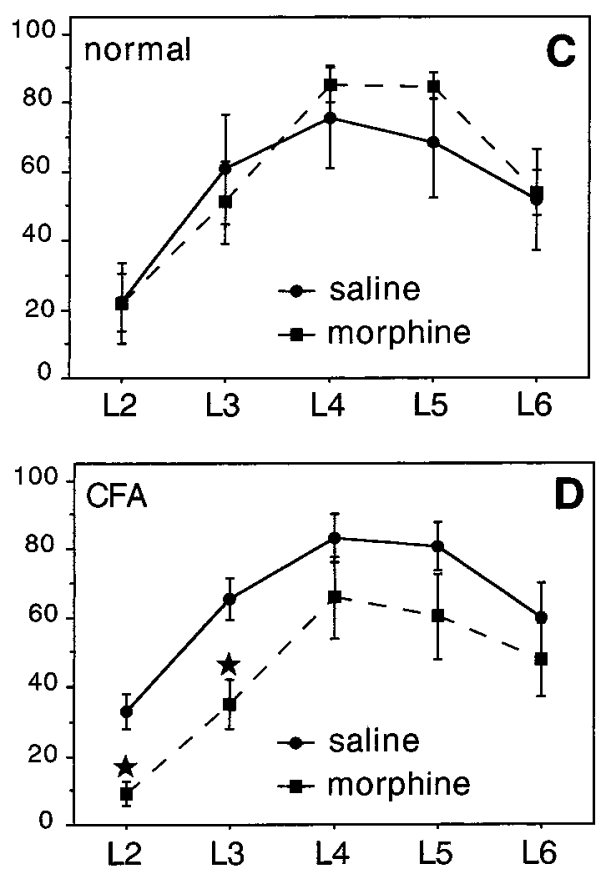

Figure 2. These graphs illustrate the effects of morphine on the percentage of neurons that contain internalized NK-1 receptor in lumbar segments L2-L6 after mechanical $(A, B)$ or thermal $(C, D)$ stimulation of the hindpaw in normal rats $(A, C)$ and in rats with inflammation $(B, D)$. Saline or morphine $(10 \mathrm{mg} / \mathrm{kg}$, s.c.) was administered before the stimulation. Results are expressed as mean \pm SEM for each group. Significance is expressed with reference to the saline group, using PLSD Fisher's test $\left({ }^{*} p<0.05 ; n=\right.$ 4). Note that (1) morphine did not affect the number of internalized neurons induced by mechanical stimulation in normal $(A)$ or CFA-treated rats $(B)$, and (2) morphine had no effect on the number of internalized neurons induced by thermal stimulation in normal rats $(C)$ but significantly decreased the number of internalized neurons in CFA-treated rats at the L2 and L3 segments $(D)$. receptor decreased rostrally and caudally, to $10-30 \%$ in L2 and $30-50 \%$ in L6 (Fig. $2 A$ ). In normal rats, pinch-evoked internalization only occurred in lamina I cell bodies and dendrites, whereas in rats with inflammation the same stimulation also induced internalization in deeper laminae III-IV and V-VI neurons. In this latter group, we also found an increase in the number of lamina I neurons that internalized the NK-1 receptor in response to pinch, to $60-70 \%$ in L2, 85-95\% in L3, 95-100\% in L4 and L5, and 70-80\% in L6 (Fig. 2B).

Morphine produced a small but statistically significant reduction of the percentage of neurons showing internalization after mechanical stimulation in normal rats $(p=0.04)$ (Fig. $2 A)$. We observed a $17 \%$ reduction in the L4 segment but found no difference in more rostral or caudal segments. In rats with inflammation, morphine had no significant effect $(p=0.25)$ (Fig. $2 B)$. If anything, morphine slightly increased the percentage of cells showing NK-1 receptor internalization. In laminae III-IV, we found no difference in the magnitude of internalization between morphine-treated and saline-treated CFA-injected rats. The combined injection of morphine and naloxone or of naloxone alone had no effect on NK-1 receptor internalization.

Noxious thermal stimulation produced by dipping the hindpaw in hot water $\left(50^{\circ} \mathrm{C}\right.$ for $\left.2 \mathrm{~min}\right)$ also evoked $\mathrm{NK}-1$ receptor internalization, in $80-85 \%$ of neurons of lamina I of L4-L5. This is less than that induced by mechanical stimulation (Fig. 2C). In contrast to mechanical stimulation, we found no difference in evoked internalization between normal rats and those with inflammation (Fig. $2 C, D$ ). In normal rats, morphine had no effect on NK-1 receptor internalization ( $p=0.6$ ) (Fig. $2 C$ ), but in rats with inflammation, morphine decreased the number of cells with internalized receptor $(p=0.04)$ (Fig. $2 D)$. The magnitude of this effect was $20-25 \%$ in L4-L5 segments. Because thermal stimulation did not induce internalization in deep dorsal horn laminae, we could not study the effect of morphine in this region. Although these small differences in the effect of opioids on the consequences of mechanical versus thermal stimulation may indicate

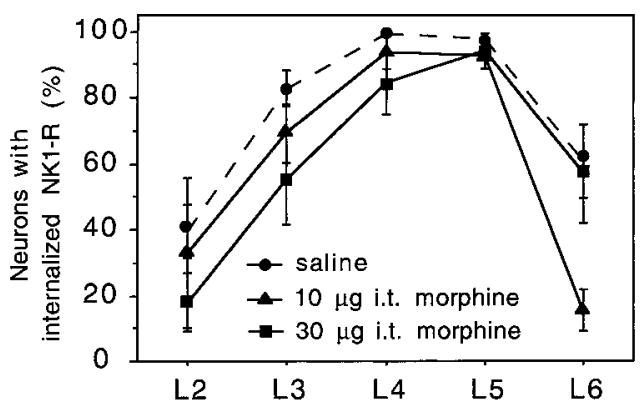

Figure 3. This graph illustrates the effects of intrathecal morphine on the percentage of neurons that contain internalized NK-1 receptor in lumbar segments (L2-L6) after mechanical stimulation of the hindpaw in normal rats. Saline $(n=8)$ or morphine, $10 \mu$ g, i.t. $(n=4)$, or $30 \mu$ g, i.t. $(n=5)$, was administered before the stimulation. Results are expressed as mean \pm SEM for each group. Morphine slightly but significantly decreased (by $\sim 20 \%$ ) the number of NK-1 receptor internalized cells, but there was no difference between the 10 or $30 \mu \mathrm{g}$ dose.

modality-specific differences in susceptibility to morphine, the inhibition in all cases was very small.

\section{Intrathecal injection of morphine}

In light of the minimal reduction of NK-1 receptor internalization after systemic injection of morphine, we also evaluated the effect of intrathecal injection. Compared with saline, intrathecal morphine produce a small, albeit significant $(p=0.012)$ reduction in the number of NK-1 receptor internalized cells (Fig. 3) induced by the $15 \mathrm{sec}$ pinch stimulus. However, there was no difference between the two doses of morphine overall; the 10 and $30 \mu \mathrm{g}$ morphine reduced the magnitude of internalization by 20 and $19 \%$, respectively. Nevertheless, the $30 \mu \mathrm{g}$ dose did tend to be somewhat more effective in L6. Finally, we evaluated the effect of intrathecal morphine on $\mathrm{NK}-1$ receptor internalization induced by direct intrathecal injection of SP, at a dose $(100 \mu \mathrm{g})$ that evoked internalization of the receptor in $100 \%$ of the NK-1 


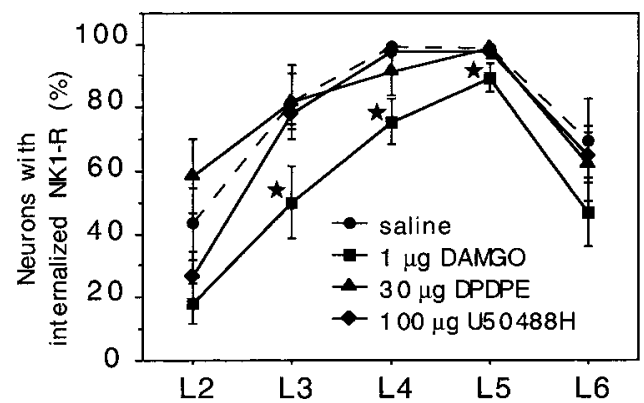

Figure 4. This graph illustrates the effects of selective mu, delta, or kappa opioid receptor agonists on the percentage of neurons that contain internalized NK-1 receptor in lumbar segments L2-L6 after mechanical stimulation of the hindpaw in normal rats. Saline or a selective opioid agonist $(1.0 \mu \mathrm{g}$, i.t., DAMGO, mu opioid receptor agonist; $30 \mu \mathrm{g}$, i.t., DPDPE, delta opioid receptor agonist; $100 \mu$ g, i.t., U50488H, kappa opioid receptor agonist) was administered before the stimulation; $n=5$ in all groups. Results are expressed as mean \pm SEM for each group. Significance is expressed with reference to the saline group, using PLSD Fisher's test $\left({ }^{*} p<0.05\right)$. Only DAMGO significantly decreased the number of NK-1 receptor internalized neurons.

receptor-positive lamina I neurons (data not shown). Although these doses of morphine are antinociceptive in most acute pain tests, we found that intrathecal morphine had no effect $(p=0.7)$ on intrathecal SP-induced NK-1 receptor internalization. Although this suggests that morphine does not interfere with SPinduced $\mathrm{NK}-1$ receptor internalization, it is possible that our use of a high dose of SP could mask such an effect.

The results above are based on estimates of internalization in populations of neurons using an all or none criterion. It is conceivable that this approach missed a small reduction of internalization in individual neurons, which could have significant functional consequences if present in large numbers of neurons that express the NK-1 receptor. To address this possibility, we counted the number of endosomes internalized in individual L4 lamina I neurons from the rats in the $30 \mu \mathrm{g}$ intrathecal morphine group and in their intrathecal saline controls (Fig. 1). In fact, there was no difference in endosome numbers between the groups (ANOVA, $p=0.6626)$. Saline animals had $78 \pm 4$ (SEM) endosomes per neuron, and the animals that received $30 \mu \mathrm{g}$ intrathecal morphine had $71.7 \pm 15$ endosomes per neuron.

\section{Intrathecal injection of receptor-selective opioid agonists}

Because there is evidence for a differential effect of receptorselective opioid ligands on SP release (Mauborgne et al., 1987; Suarez-Roca and Maixner, 1993; Zachariou and Goldstein, 1996a,b) (for review, see Bourgoin et al., 1994) and because anatomical evidence indicates that there is a differential localization of the different opioid receptor subtypes within primary afferent populations, (Mansour et al., 1994; Minami et al., 1995; Zhang et al., 1998), we repeated the experiment using selective agonists for the mu, delta, and kappa opioid receptors. Again, we used mechanical stimulation of the hindpaw to induce receptor internalization. We found that a very high concentration $(1.0 \mu \mathrm{g}$, i.t.) of DAMGO (a selective mu opioid receptor agonist) significantly decreased the number of neurons with internalized NK-1 receptor by $31 \%$ in L4 ( $p=0.004$ ) (Fig. 4). Neither DPDPE (a selective delta opioid receptor agonist, $30 \mu \mathrm{g}$, i.t.) nor U-50488H (a selective kappa opioid receptor agonist, $100 \mu \mathrm{g}$, i.t.) had a significant effect: DPDPE and U-50488H produced a 6.0 and $1.0 \%$ reduction, respectively (Fig. 4 ).
Effects of an NK-1 receptor antagonist, GR 205171, on internalization of the NK-1 receptor induced by peripheral stimulation

Normal rats

As we observed previously (Abbadie et al., 1997), the selective NK-1 receptor antagonist GR 205171 significantly reduces noxious stimulus-induced internalization of the NK-1 receptor in spinal cord neurons, indicating that internalization requires ligand binding. In the present study we found that the effect of GR 205171 increased with increasing dose. Thus, $1.0 \mathrm{mg} / \mathrm{kg}$ slightly decreased the number of cells that internalized the NK-1 receptor $(<10 \%)$, but this decrease was not significantly $(p=0.19)$ different from that of the saline-treated group (Fig. 5). At 10 $\mathrm{mg} / \mathrm{kg}$, GR 205171 significantly $(p<0.0001$ ) (Fig. 5) decreased the number of cells that internalized the NK-1 receptor. In the L4 segment the decrease was $77.5 \%$ (Fig. 5). Qualitatively, we observed that after GR 205171, endosomal and membrane labeling often coexisted in neurons; i.e., internalization was rarely complete. Moreover, endosomes appeared smaller than in salinetreated rats (Fig. 6). In contrast to the morphine animals in which no change in extent of endosomal labeling was found, this labeling pattern is suggestive of decreased NK-1 receptor activation of individual neurons, which raises the possibility that we are underestimating the effects of GR 205171.

Our inability to produce a profound or consistent reduction of NK-1 receptor internalization with systemic morphine alone may have resulted from a saturation of the noxious stimulus-induced response. To test this possibility we coadministered morphine with a low dose of an NK-1 receptor antagonist. We found that the combined administration of morphine $(10 \mathrm{mg} / \mathrm{kg}$, s.c.) and GR 205171 (1.0 mg/kg, s.c.) at doses that were ineffective when administered alone, significantly $(p<0.0001)$ decreased the number of neurons that internalized NK-1 receptor in response to noxious stimulation (Fig. 5). Internalization in the group that received both morphine and the NK-1 receptor antagonist was decreased by $45 \%$ in the L4 segment compared with the salinetreated group. The rats that received the two drugs concurrently also showed a significant reduction in the percentage of cells showing internalization compared with the group that received morphine alone $(p<0.01)$ or the group that received GR 205171 at $1.0 \mathrm{mg} / \mathrm{kg}(p<0.01)$. On the other hand, the combination was significantly less effective in reducing internalization of the NK-1 receptor $(p<0.05)$ than was the NK-1 receptor antagonist at the highest dose $(10 \mathrm{mg} / \mathrm{kg})$.

\section{Rats with an inflamed hindpaw}

Because there is an increase in levels of SP and its precursor mRNA in dorsal root ganglion cells and an upregulation of NK-1 receptor in the dorsal horn (Kiyama et al., 1988; Donnerer et al., 1993; Hanesch et al., 1993; Mapp et al., 1993; Schafer et al., 1993; Abbadie et al., 1996) in the setting of inflammation, we next evaluated the effect of NK-1 receptor antagonists and morphine in this context. In animals with inflammation, we again found a dose-related effect of GR 205171. Thus, although $1.0 \mathrm{mg} / \mathrm{kg} \mathrm{GR}$ 205171 had no effect on the percentage of cells that internalized the NK-1 receptor in lamina I through VI (Fig. 3), $10 \mathrm{mg} / \mathrm{kg}$ GR 205171 significantly $(p<0.0001)$ (Fig. 7) decreased the number of cells that internalized the NK-1 receptor. In lamina I of the L4 segment, we observed a decrease of $50 \%$ (Fig. 7), and in laminae III-IV and V-VI, GR $205171(10 \mathrm{mg} / \mathrm{kg})$ completely blocked internalization of the NK-1 receptor (Figs. $7 B, C$ ). We next found 


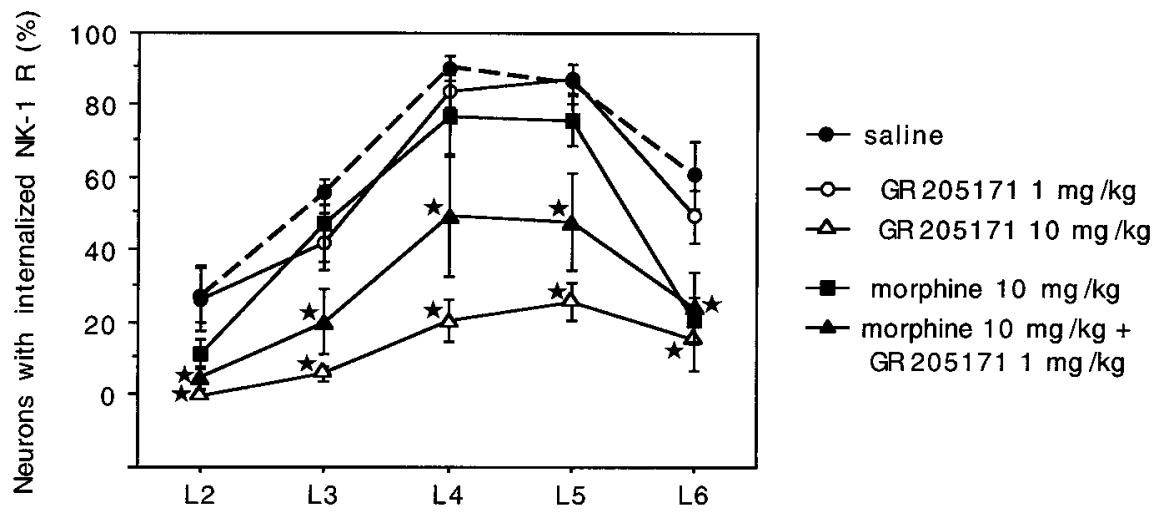

Figure 5. This graph illustrates the effects of the NK-1 receptor antagonist GR 205171 alone or in combination with morphine on the percentage of neurons that contain internalized NK-1 receptor in lumbar segments L2-L6 after mechanical stimulation (pinch for 15 sec) of the hindpaw in normal rats. Saline or GR 205171, with or without morphine, was administered before the stimulation; $n=5$ in all groups. Results are expressed as mean \pm SEM for each group. Significance is expressed with reference to the saline group, using PLSD Fisher's test $\left({ }^{*} p<0.05\right)$. GR $205171(10 \mathrm{mg} / \mathrm{kg})$ significantly reduced the number of internalized cells. A lower dose of GR $205171(1.0 \mathrm{mg} / \mathrm{kg})$ or morphine $(10 \mathrm{mg} / \mathrm{kg}) \mathrm{given}$ alone had no significant effect. However, GR $205171(1.0 \mathrm{mg} / \mathrm{kg})$ in combination with morphine $(10 \mathrm{mg} / \mathrm{kg})$, significantly reduced the number of internalized neurons evoked by the mechanical stimulation.
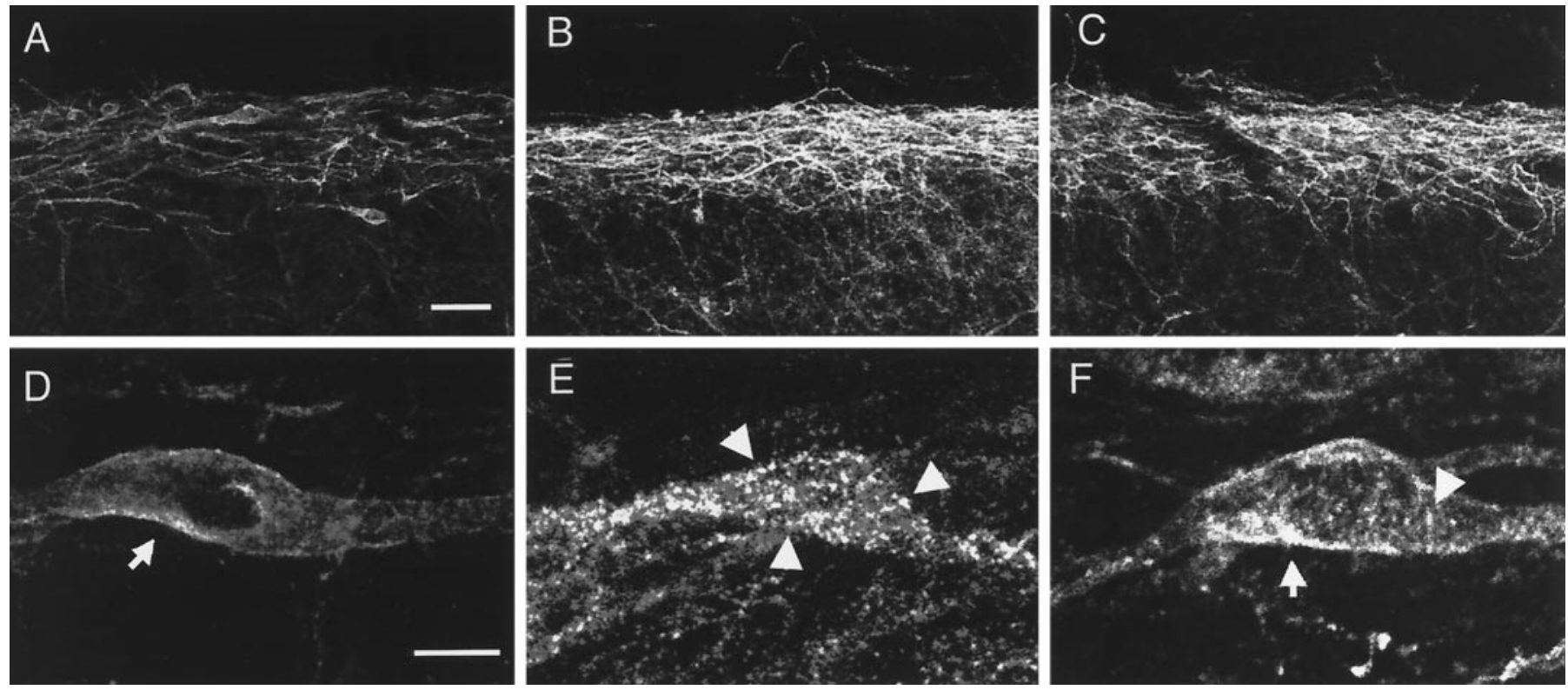

Figure 6. These confocal images of NK-1 receptor labeling in lamina I illustrate the decrease in internalization after systemic injection of the NK-1 receptor antagonist GR 20517: $A, D$, no stimulus; $B, E, 15 \mathrm{sec}$ pinch; $C, F$, pinch with GR 205171, $10 \mathrm{mg} / \mathrm{kg}$, s.c. White arrows and white arrowheads indicate membrane and endosomal labeling, respectively. Note the qualitative difference in NK-1 receptor labeling in neurons showing internalization in the presence of GR 205171; there is a decrease in endosome size and number and there is residual membrane labeling. Scale bars (shown in $A$ for $A-C$ ): $50 \mu \mathrm{m}$; (shown in $D$ for $D-F$ ): $20 \mu \mathrm{m}$.

that the combined administration of morphine $(10 \mathrm{mg} / \mathrm{kg}$, s.c. $)$ and GR 205171 (1.0 mg/kg, s.c.) decreased the number of NK-1 receptor internalized cells. However, this effect was only significant in lamina I of L2-L3. The two drugs were more potent in normal rats $(56 \%$ decrease of the area under the curve) than in the CFA-treated group (21.5\% decrease).

\section{Correlation of NK-1 receptor-induced "activity" and its internalization}

Although we assume that NK-1 receptor internalization provides a measure of the functional consequences of SP release (e.g., increased neuronal activity), this relationship has not been demonstrated in neurons. To make useful conclusions about neuronal activity in the dorsal horn based on the preceding data we needed to establish that there is a precise relationship between NK-1 receptor internalization and NK-1 receptor-mediated signaling. To address this question, we evaluated tachykinin-induced increases in intracellular calcium (Heath et al., 1994; Garland et al., 1996) and correlated these responses with the magnitude of NK-1 receptor internalization in primary cultures of spinal cord. Figure $8 A$ illustrates that addition of SP to the bathing medium of primary spinal cord cultures rapidly increased intracellular calcium levels and induced NK-1 receptor internalization in neurons and glia in a dose-dependent manner. The $\mathrm{EC}_{50}$ values for total calcium influx and number of NK-1 receptor-positive endosomes were $8.74 \mathrm{~nm}(95 \% \mathrm{CI}: 2.58-29.6 \mathrm{~nm})$ and $14.28 \mathrm{~nm}(95 \% \mathrm{CI}$ : 2.35-86.8 nM), respectively, and the overall dose-response curves 
Figure 7. This graph illustrates the effects of the NK-1 receptor antagonist GR 205171, alone or in combination with morphine, on the percentage of neurons that contain internalized NK-1 receptor in lumbar segments L2-L6 after mechanical stimulation (pinch for 15 sec) of the hindpaw in CFA-treated rats. Saline or GR 205171, with or without morphine, was administered before the stimulation; $n=5$ in all groups. Results are expressed as mean \pm SEM for each group. Significance is expressed with reference to the saline group, using PLSD Fisher's test $\left({ }^{*} p<0.05\right)$. GR $205171(10 \mathrm{mg} / \mathrm{kg})$ significantly decreased the number of internalized cells in lamina I $(A)$. In laminae III-V I $(B$, $C)$ it completely blocked the internalization. Neither GR $205171(1.0 \mathrm{mg} / \mathrm{kg})$ nor morphine $(10 \mathrm{mg} / \mathrm{kg})$ given alone had a significant effect on the number of internalized cells. However, the combination of GR $205171(1.0 \mathrm{mg} / \mathrm{kg})$ and morphine $(10 \mathrm{mg} / \mathrm{kg})$ significantly decreased internalization in neurons of the L2 and L3 segments.
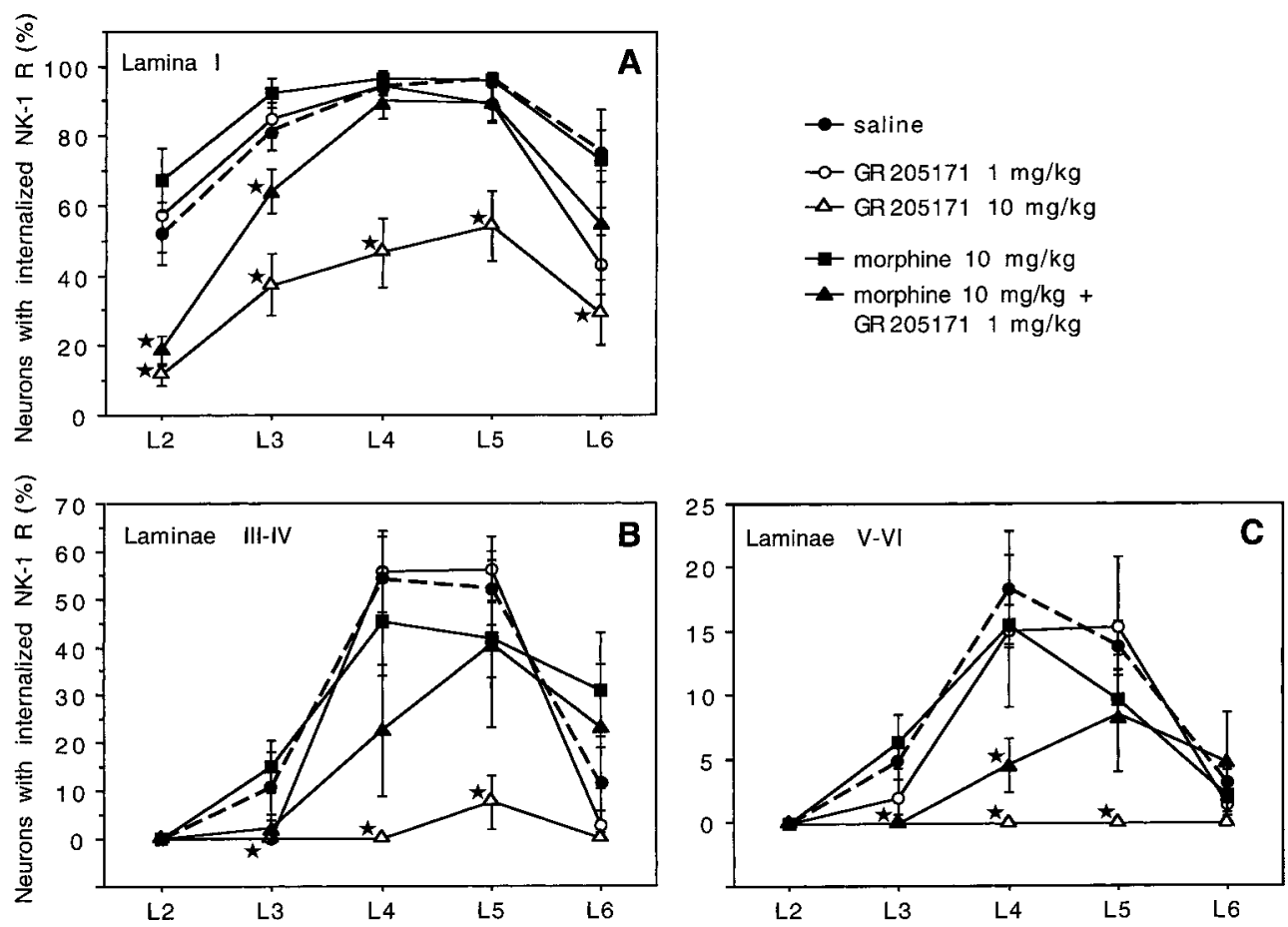

did not differ (two-way ANOVA for dose and measure; $p=0.861$ ) (Fig. 8B).

Interestingly, not only were the dose-response curves for the magnitude of SP-induced calcium signaling and NK-1 receptor internalization virtually identical, but similar curves were obtained when we measured the percentage of neurons that responded over a threshold value for either calcium signaling or internalization (Fig. $8 C$ ). The $\mathrm{EC}_{50}$ values for the percentage of neurons responding were $8.48 \mathrm{~nm}(95 \% \mathrm{CI}$ : $5.23-13.73 \mathrm{~nm})$ for increases in intracellular calcium concentration and $15.74 \mathrm{nM}$ (95\% CI: $13.64-18.17 \mathrm{~nm}$ ) for NK-1 receptor internalization. There was no difference between the dose-response curves for percentage of neurons responding with a calcium increase and percentage responding with $\mathrm{NK}-1$ receptor internalization (twoway ANOVA for dose and measure; $p=0.978$ ).

\section{Morphine regulation of Fos expression in NK-1 receptor-expressing neurons}

Although we found that morphine had a marginal effect on NK-1 receptor internalization, inhibition of SP release is only one of many mechanisms through which morphine could alter the activity of SP-responsive neurons. Postsynaptic inhibition of these neurons or of excitatory interneurons that activate lamina I cells is also likely to occur. To test this hypothesis, we used a doublelabeling method to visualize noxious stimulus-evoked Fos protein and the NK-1 receptor simultaneously, so that we could evaluate the effect of morphine on the activity (i.e., postsynaptic response) of NK-1 receptor-positive neurons. This allowed us to look at differences in opioid regulation of lamina I neuron activity that correlate with NK-1 receptor expression and activation by SP. Of particular interest was whether Fos could be blocked in neurons in which NK-1 receptor internalization persists. We examined the effect of morphine on both (1) neuronal activity directly induced by intrathecal injection of SP and (2) neuronal activity induced by the noxious mechanical stimulation described above.

\section{Morphine modulation of the central effects of intrathecal SP}

First, we found that intrathecal SP $(100 \mu \mathrm{g})$ was a very effective stimulus for the induction of Fos in dorsal horn neurons. In fact, almost all NK-1 receptor-LI neurons expressed Fos after intrathecal SP, but, interestingly, Fos was also expressed in NK-1 receptor-negative cells (Table 1), including many in lamina II. We presume that these neurons lie downstream of the NK-1 receptor-LI neurons of lamina I. Because lamina II is almost devoid of NK-1 receptor-expressing neurons, we only quantified the effect of morphine in lamina I neurons. In saline-injected rats, we counted 57.1 \pm 4.3 Fos-LI nuclei per $30 \mu \mathrm{m}$ sagittal section in the lumbar enlargement (L2-L6). Morphine (10 mg/kg, s.c.) had no effect on the number of lamina I Fos-LI neurons induced by SP (Table 1$)(p=0.93)$. This was true for both NK-1 receptorpositive and -negative cells (Table 1).

\section{Effects of morphine on noxious mechanical stimulation-induced Fos expression}

After mechanical stimulation, the number of neurons labeled for both Fos and NK-1 receptor differed according to the segmental level. The largest number was in the segments that receive greater innervation from the stimulated area, namely L4-L5 (i.e., where the Fos induction is greatest). In the L4-L5 segments, 75-80\% of the NK-1 receptor-LI cells were also Fos-LI but only $18 \%$ in L2 and $50-55 \%$ in L3 or L5 were double-labeled. By contrast, the percentage of Fos-LI cells that were NK-1 receptor-LI was constant over the lumbar cord; $15-25 \%$ of Fos-LI neurons were NK-1 receptor-LI in segments from L2 to L6.

In contrast to the lack of effect of morphine on SP-induced Fos expression, we found that morphine $(10 \mathrm{mg} / \mathrm{kg}$, s.c. $)$ significantly $(p<0.001)$ decreased Fos-LI expression in lamina I neurons evoked by mechanical stimulation. On the other hand, we found a difference in the ability of morphine to prevent Fos-LI expression in NK-1 receptor-positive versus NK-1 receptor-negative 

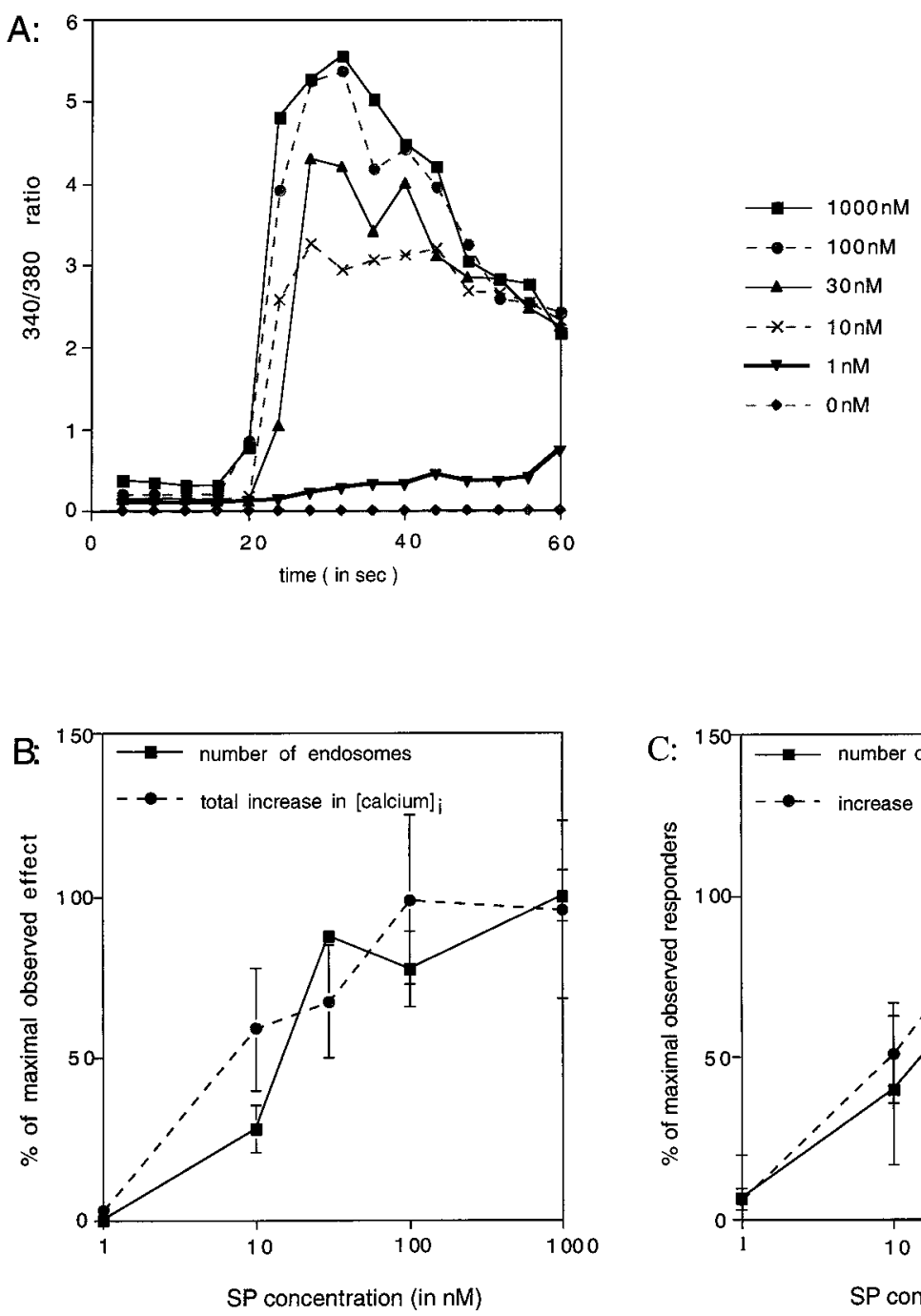

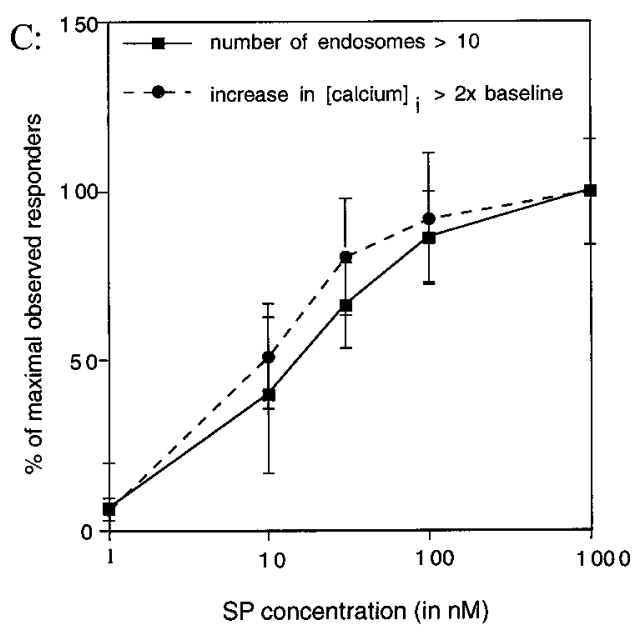

Figure 8 . These graphs illustrate the dose-response relationship between SP concentration and increases in intracellular calcium concentration and NK-1 receptor internalization in primary spinal cord cultures. $A$, Average $340 / 380 \mathrm{~nm}$ fluorescence ratio in fura-2 AM-loaded primary spinal cord cultures during the application of varying doses of SP. Only cells showing average increases in 340/380 ratio that were at least twice the average baseline value are included in this graph; $n=4-8$ coverslips. There is a significant effect of SP dose on the 340/380 ratio (ANOVA: $p=0.0258$ ). $B$, Percentage of maximal possible effect for both the number of NK-1 receptorpositive endosomes observed and the total calcium influx observed in the first $40 \mathrm{sec}$ with application of varying concentrations of SP. The maximal number of endosomes/neuron observed was 22.65; untreated cultures contained 6.95 endosomes/neuron ( $n=4$ coverslips). The maximal total increase in $340 / 380$ ratio was 23.78 ; untreated cultures showed a total increase of $0 . C$, Percentage of maximal possible responders for calcium changes and increases in endosome number. Thresholds were set at 10 endosomes for NK-1 receptor internalization and twice baseline for increases in intracellular calcium. The maximal number of responders for NK-1 receptor internalization was $100 \%$; untreated cultures showed $25 \%$ of neurons responding. The maximal number of responders for increases in intracellular calcium was $50.6 \%$; untreated cultures showed $0 \%$ responding.

Table 1. Effects of morphine on double-labeled cells (Fos, NK-1 receptor)

\begin{tabular}{lcclll} 
Groups & $n$ & Total Fos & $\begin{array}{l}\text { Fos in NK-1 } \\
\text { R-negative cells }\end{array}$ & $\begin{array}{l}\text { Fos in NK-1 } \\
\text { R-positive cells }\end{array}$ & $\begin{array}{l}\text { NK-1 R-positive and } \\
\text { Fos-negative cells }\end{array}$ \\
\hline SP i.t. + saline & 5 & $57.1 \pm 4.3$ & $41.4 \pm 3.3$ & $15.7 \pm 1.6$ & $4.3 \pm 3.1$ \\
SP i.t. + morphine & 4 & $57.9 \pm 9.9$ & $39.9 \pm 11.7$ & $19.9 \pm 4.5$ & $2.2 \pm 1.3$ \\
\hline
\end{tabular}

i.t., Intrathecal.

neurons (Figs. 9, 10). In L4-L5, morphine produced a $60 \%$ decrease of Fos expression in NK-1 receptor-negative neurons but only a $20-40 \%$ decrease in cells that were NK-1 receptor-LI (Fig. 10). This result suggests that morphine was not as effective on cells activated by SP.

\section{DISCUSSION}

\section{Opioid regulation of the central effects of SP release from primary afferents}

With some exceptions (Kuraishi et al., 1983; Lang et al., 1991), opioid inhibition of SP release from primary afferent fibers has been demonstrated in both an in vitro and an in vivo setting. Despite these results, there is no information on the functional significance of the opioid reduction of SP release. In the present study we used a measure of the postsynaptic response to a neuron's interaction with SP, namely internalization of the NK-1 receptor, to address this question. We found a modest reduction in NK-1 receptor internalization with opioids, but the internalization that persisted was more striking. We estimate that at least $80 \%$ of the tachykinin signaling is intact after morphine administration, at doses that produce analgesia in awake animals. The fact that other compounds, such as baclofen, can greatly reduce noxious stimulus-evoked NK-1 receptor internalization further underscores the ineffectiveness of opioids (Riley et al., 1997; Marvizon et al., 1999). We conclude that NK-1 receptor signaling is only slightly reduced under conditions of profound opioid analgesia.

Importantly, we provide new evidence that NK-1 receptor internalization is indeed a reliable and quantifiable indicator of the extent of NK-1 receptor activation. Thus, SP-induced changes in intracellular calcium concentration, which provide a direct measure of the second messenger signaling that is thought to 

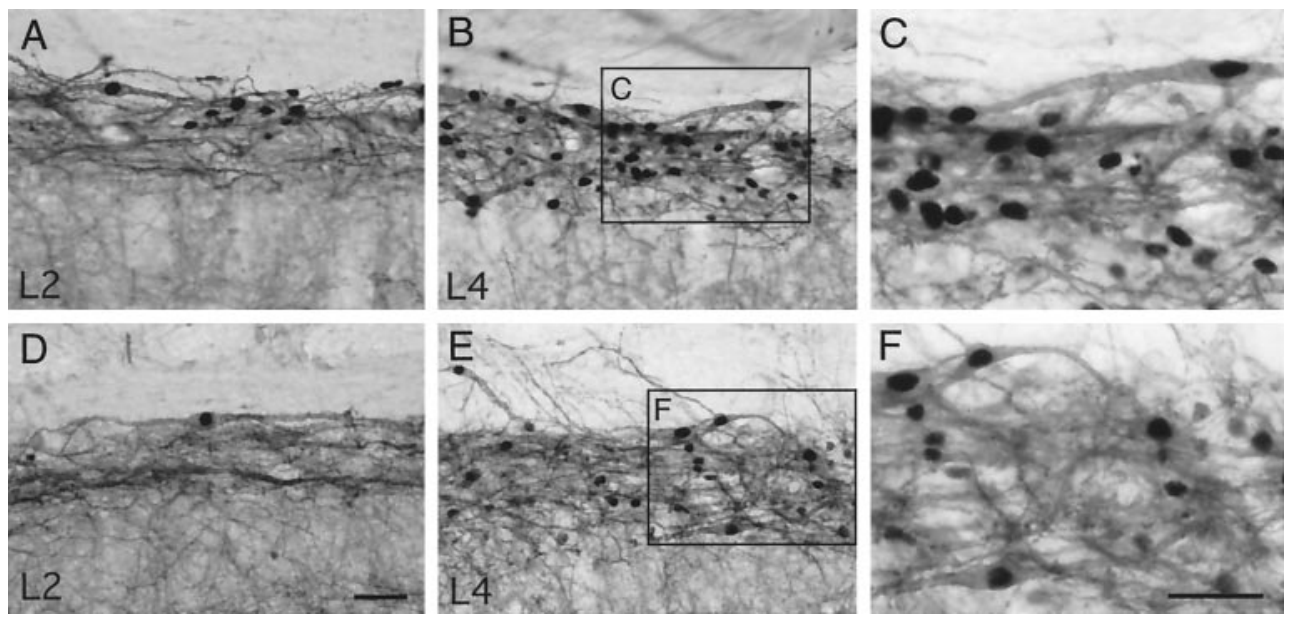

Figure 9. These photomicrographs illustrate the effect of morphine on noxious stimulus-evoked expression of Fos-like immunoreactivity in NK-1 receptor immunoreactive neurons in lamina I. Each figure is from sagittal sections of the lumbar spinal cord. In all examples, the noxious stimulus was a $15 \mathrm{sec}$ pinch of the hindpaw. $A-F$, Double labeling for Fos-LI (black nuclei) and NK-1 receptor-LI ( ray cytoplasm in cell bodies and dendrites). $A-C$, Rats that received subcutaneous saline; $D-F$, rats that received subcutaneous morphine. After morphine, the number of Fos-LI neurons decreased significantly $(D)$. The effect of morphine on the number of double-labeled (Fos and NK-1 receptor-LI) neurons was less pronounced $(E, F)$. Scale bars (shown in $D$ for $A, B, D, E$ ): $50 \mu \mathrm{m}$; (shown in $F$ for $C, F$ ): $20 \mu \mathrm{m}$.

A NK-1 receptor-LI negative neurons

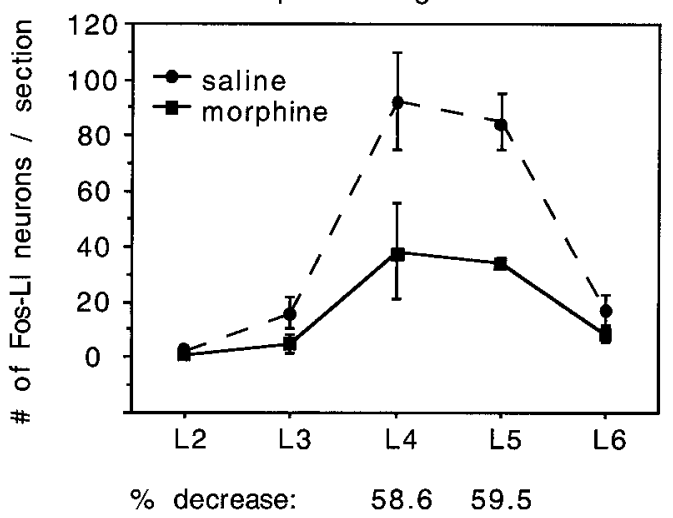

B NK-1 receptor-LI positive neurons

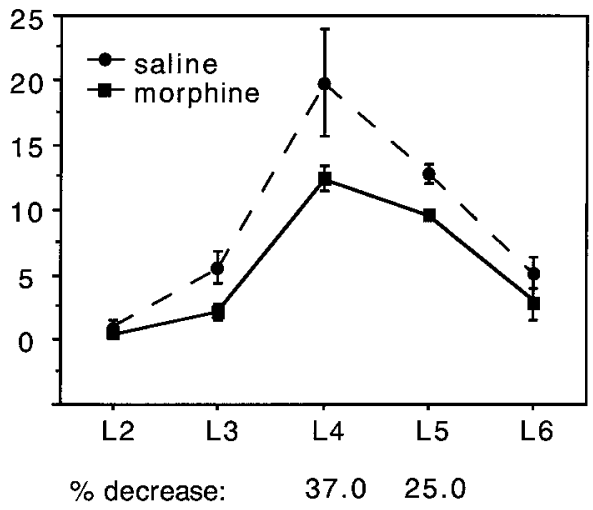

Figure 10. These graphs illustrate the effects of morphine on Fos-like immunoreactivity in neurons of lamina I in lumbar segments L2-L6 after mechanical stimulation of the hindpaw in normal rats. Saline or morphine was administered before the stimulation; $n=5$ in all groups. Results are expressed as mean \pm SEM for each group. Significance is expressed with reference to the saline group, using PLSD Fisher's test $\left({ }^{*} p<0.05\right)$. $A$, Number of Fos-LI nuclei in neurons that are not NK-1 receptor-LI. B, Number of Fos-LI nuclei in neurons that are NK-1 receptor-LI. Note that there is a greater decrease in Fos-LI neurons that are not NK-1 receptor-LI in the lumbar segments L4-L5. These segments also contain a high percentage of neurons with NK-1 receptor internalization after mechanical stimulation.

underlie NK-1 receptor actions, were highly correlated with the magnitude of NK-1 receptor internalization. This was the case whether the number of NK-1 receptor-containing endosomes per neuron or the percentage of cells containing greater than a threshold number of endosomes was quantified. Although this internalization cannot discriminate between the effects of SP and neurokinin A (NKA) (Maggi and Schwartz, 1997), it allows measurement with cellular resolution and can be performed without previous surgical manipulation, a procedure that itself must induce tachykinin release.

In light of the extensive literature demonstrating decreases in SP release, the minimal effects of opioids on dorsal horn tachykinin signaling that we observed were surprising. These differing results, however, are readily reconciled. Because bound SP is internalized along with the NK-1 receptor (Bunnett et al., 1995), those studies that assayed extracellular SP concentrations only measured SP that was not receptor bound. In other words, studies of the extracellular concentrations of SP monitor only peptide that is in excess of that necessary for receptor activation and internalization. Similarly, the magnitude of NK-1 receptor internalization does not provide a measure of the total amount of SP released. Instead, and in contrast to traditional release studies, $\mathrm{NK}-1$ receptor internalization provides a measure of the amount of SP that interacts with an NK-1 receptor (Fig. 11A).

According to this reasoning, opioid effects might have the following consequences. If morphine were to reduce SP release to a level just sufficient to activate all nearby receptors, then NK-1 receptor internalization would be saturated, and thus SP effects on target neurons would still be maximal. However, concurrently, the amount of excess extracellular SP would decrease tremendously. Thus, small alterations of the amount of SP that is released might have little effect on the resulting activation of lamina I neurons but could greatly affect the levels of SP collected from CSF (Fig. 11B). In support of this hypothesis, we found that 


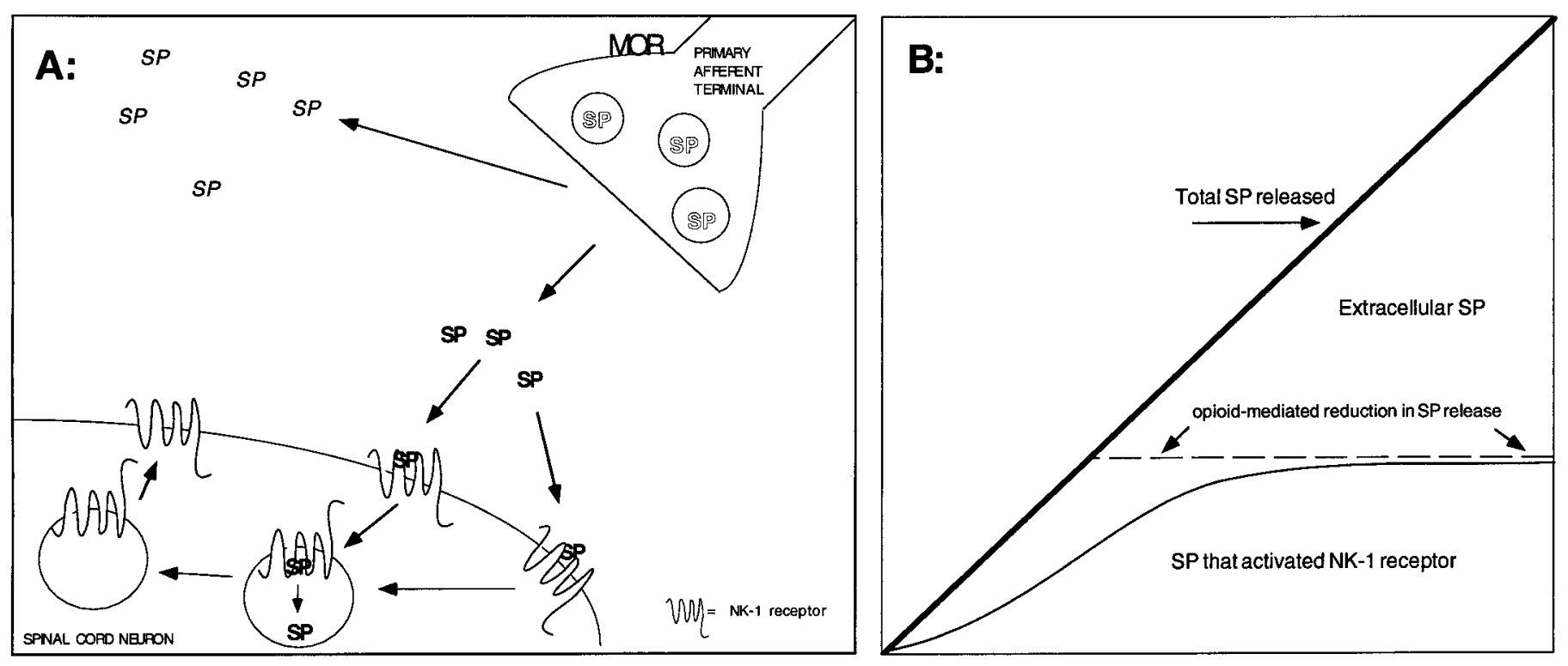

Figure 11. A, Substance $\mathrm{P}$ (hollow-letter SP) is contained in dense-core vesicles in terminals of small-diameter primary afferents and in some spinal cord interneurons. After noxious stimulation, SP is released. Some percentage of the released substance P (SP) diffuses to target cells, where it interacts with and activates NK-1 receptors. This SP is internalized along with the NK-1 receptor into endosomes. Acidification of these endosomes dissociates the SP from the NK-1 receptor. The SP is degraded, and the NK-1 receptor is recycled to the membrane. Unbound SP $(S P)$ diff uses into the extracellular space and eventually into the CSF, where it may be broken down by endopeptidases. Previous release studies measured the amount of substance P in the CSF or extracellular space $(S P)$. Because the SP that binds and activates the NK-1 receptor is degraded intracellularly, these studies measured essentially the overflow of substance P, i.e., the released content of the peptide that did not have a postsynaptic effect. In contrast, we take advantage of the fact that activated NK-1 receptors internalize with their associated ligand. This provides a measure of the amount of released peptide that has a functional, postsynaptic effect via the NK-1 receptor (SP). B. The total amount of SP released can be divided into two measurable pools: SP that diff uses extracellularly and SP that binds the NK-1 receptor and is internalized. The amount of SP that enters each of these two pools for any given amount of SP released is not known. However, the NK-1 receptor binding SP component is saturable; the extracellular SP pool is not. The consequences of this difference are depicted here. Changes in extracellular SP are greatest and most easily detectable when the NK-1 receptor binding pool is saturated. If there are no further NK-1 receptor sites to activate, however, these changes in SP release will have no effect on SP-mediated postsynaptic signaling in the spinal cord dorsal horn. We have illustrated a hypothetical opioid-mediated reduction of the extracellular content of SP that can occur (dashed line) without an observable effect on NK-1 receptor-mediated signaling.

a combination of a low dose of the NK-1 receptor antagonist GR 205171 and morphine decreased NK-1 receptor internalization to a greater extent than did either drug alone. We suggest that addition of an ineffective dose of NK-1 receptor antagonist uncovered the relatively large decrease in total SP released.

\section{Opioid regulation of SP release during inflammation}

Behavioral studies have shown that morphine is more effective in rats with a persistent inflammation of the hindpaw than in their normal counterparts (Colpaert, 1979; Kayser and Guilbaud, 1983). This inflammation is associated with an increase in SP and NK-1 receptor levels in primary afferents and in spinal cord (Donnerer et al., 1993; Hanesch et al., 1993; Mapp et al., 1993; Schafer et al., 1993; Abbadie et al., 1996). We have also observed increased noxious stimulus-evoked internalization of the NK-1 receptor in lamina I neurons in the setting of persistent injury (Abbadie et al., 1997). Together these results suggest that opioid regulation of SP release may be more effective and relevant under inflammatory conditions. To examine this possibility, we repeated the NK-1 receptor internalization studies in CFA-treated animals. Rather than having an increased efficacy in this condition, morphine was even less able to decrease NK-1 receptor internalization than it was in normal rats. The NK-1 receptor antagonist GR 205171 also produced less of a reduction.

Although this result suggests that the increased analgesic efficacy of opioids in an inflammatory model is not caused by enhanced regulation of tachykinin signaling, the decreased effect of morphine and GR 205171 may be explained by the upregulation of SP and the increase in SP release that characterizes this model. Because GR 205171 is a competitive antagonist, increased release of SP from primary afferents should reduce the activity of a given dose of NK-1 receptor antagonist. It would also make opioid-induced decreases in release more difficult to detect. That is, if the response had saturated, a small opioid effect would be lost. Finally, an inflammation-induced expression of SP in largediameter sensory neurons, which do not express mu opioid receptors (Neumann et al., 1996), would also make detection of opioid inhibitory effects less likely. On the basis of our results, we conclude that although opioids can reduce SP release, this is probably not a major mechanism by which opioids produce analgesia. We suggest that an opioid action on lamina II interneurons or non-SP-containing primary afferent terminals is likely to be more important for production of spinal opioid analgesia.

\section{Functional consequences of activation of NK-1 receptor-containing neurons}

We previously reported that morphine does not decrease noxious stimulus-evoked Fos expression in lamina I spinoparabrachial neurons (Jasmin et al., 1994) and suggested that signaling via the spinoparabrachial pathway is largely unchanged under conditions of opioid analgesia. It is thus of interest that a large percentage $(70 \%)$ of lamina I neurons that project to the parabrachial nucleus express the NK-1 receptor (Ding et al., 1995). Given the extensive overlap between these populations, our results provide 
a possible explanation for the fact that this pathway is refractory to opioid inhibition. Specifically, it is possible that the preservation of Fos expression in lamina I projection neurons reflects the fact that opioids do not sufficiently reduce the SP input to these neurons. Thus, continued release of SP (and probably other neurotransmitters) could maintain activity in this pathway, even under conditions in which other neurons are inhibited. Interestingly, electrophysiological studies have shown that although morphine fairly consistently inhibits deeper lamina $\mathrm{V}$ neurons, a significant population of lamina I and II neurons show enhanced responsiveness in the presence of morphine (Woolf and Fitzgerald, 1981; Willcockson et al., 1986; Jones et al., 1990; Magnuson and Dickenson, 1991; Craig and Serrano, 1994). It is likely that these neurons correspond to those in which Fos expression is not reduced by morphine and include the NK-1 receptor-positive population in lamina I.

\section{Clinical relevance}

In a recent study, we reported that mice lacking the preprotachykinin gene showed behavioral deficits in tests of nociception only when intense mechanical, thermal, or chemical test conditions were used (Cao et al., 1998). Previous studies that detected opioid-mediated decreases in SP release also used extreme stimuli, for example $47 \mathrm{~mm} \mathrm{KCl}$ in slices (Jessell and Iversen, 1977), bilateral sciatic nerve stimulation, or intrathecal capsaicin (Yaksh et al., 1980). Our finding that only highly noxious stimuli induce NK-1 receptor internalization in the spinal cord of the normal rat suggests that tachykinins are only released under such conditions (Abbadie et al., 1997). Because morphine is not particularly effective in blocking pain produced by the highly noxious acute stimuli that we found are required to promote SP release, but is effective against most clinically encountered pains, we suggest that SP is not involved in pain conditions most sensitive to morphine treatment. It follows that the inability of morphine to prevent NK-1 receptor signaling induced by the stimuli that release SP may underlie its ineffectiveness against these types of pain. This hypothesis may also explain the ineffectiveness of NK-1 receptor antagonists as analgesics in some clinical trials (Goldstein et al., 1997); the pain conditions tested may not involve significant SP-induced activity.

Given that lamina I NK-1 receptor neurons contribute to the transmission of nociceptive messages and that morphine is relatively ineffective at reducing their activity, NK-1 receptor antagonists may be useful as adjunct therapies with morphine to control severe acute pain conditions that are refractory to morphine treatment. This possibility is supported by the observation of increased potency of opioids in SP-NKA knock-out mice in tests of nociception in which SP was shown to be required (Cao et al., 1998). Of course, any compound that would sufficiently inhibit NK-1 receptor-mediated activity in lamina I would also be useful. As noted above, the GABA B receptor agonist baclofen and NMDA receptor antagonists, respectively, reduce NK-1 receptor internalization under in vivo and in vitro conditions (Marvizon et al., 1997, 1999; Riley et al., 1997). Although the mechanism through which these compounds regulate the release of SP from primary afferent terminals differs (Teoh et al., 1996; Liu et al., 1997), the result on the magnitude of NK-1 receptor internalization is similar, indicating that these compounds should also prevent tachykinin-mediated "pain" transmission and thus improve opioid analgesia.

\section{REFERENCES}

Abbadie C, Brown J, Mantyh P, Basbaum A (1996) Spinal cord substance $\mathrm{P}$ receptor immunoreactivity increases in both inflammatory and nerve injury models of persistent pain. Neuroscience 70:201-209.

Abbadie C, Trafton J, Liu H, Mantyh PW, Basbaum AI (1997) Inflammation increases the distribution of dorsal horn neurons that internalize the neurokinin-1 receptor in response to noxious and non-noxious stimulation. J Neurosci 17:8049-8060.

Aimone L, Yaksh T (1989) Opioid modulation of capsaicin-evoked release of substance $\mathrm{P}$ from rat spinal cord in vivo. Peptides 10:1127-1131.

Bourgoin S, Benoliel J, Collin E, Mauborgne A, Pohl M, Hammon M, Cesselin F (1994) Opioidergic control of the spinal release of neuropeptides. Possible significance for the analgesic effects of opioids. Fund Clin Pharmacol 8:307-321.

Brown JL, Liu H, Maggio JE, Vigna SR, Mantyh PW, Basbaum AI (1995) Morphological characterization of substance $\mathrm{P}$ receptorimmunoreactive neurons in the rat spinal cord and trigeminal nucleus caudalis. J Comp Neurol 356:327-344.

Bunnett NW, Dazin PF, Payan DG, Grady EF (1995) Characterization of receptors using cyanine 3-labeled neuropeptides. Peptides 16:733-740.

Cao YQ, Mantyh PW, Carlson EJ, Gillespie A-M, Epstein CJ, Basbaum AI (1998) Primary afferent tachykinins are required to experience moderate to intense pain. Nature 392:390-394.

Colpaert F (1979) Can chronic pain be suppressed despite purported tolerance to narcotic analgesia. Life Sci 24:1201-1210.

Craig A, Serrano L (1994) Effects of systemic morphine on lamina I spinothalamic tract neurons in the cat. Brain Res 636:233-244.

De Koninck Y, Henry J (1991) Substance P-mediated slow excitatory postsynaptic potential elicited in dorsal horn neurons in vivo by noxious stimulation. Proc Natl Acad Sci USA 88:11344-11348.

Ding Y-Q, Takada M, Shigemoto R, Mizuno N (1995) Spinoparabrachial tract neurons showing substance $\mathrm{P}$ receptor-like immunoreactivity in the lumbar spinal cord of the rat. Brain Res 674:336-340.

Donnerer J, Schuligoi R, Stein C, Amann R (1993) Upregulation, release and axonal transport of substance $\mathrm{P}$ and calcitonin gene-related peptide in adjuvant inflammation and regulatory function of nerve growth factor. Regul Pept 46:150-154.

Duggan A, Hendry I, Morton C, Hutchinson W, Zhao Z (1988) Cutaneous stimuli releasing immunoreactive substance $\mathrm{P}$ in the dorsal horn of the cat. Brain Res 451:261-273.

Garland AM, Grady EF, Lovett M, Vigna SR, Frucht MM, Krause JE, Bunnett NW (1996) Mechanisms of desensitization and resensitization of $\mathrm{G}$ protein-coupled neurokinin-1 and neurokinin-2 receptors. Mol Pharmacol 49:438-446.

Goldstein D, Wang O, Saper J, Stolz R, Siberstein S, Mathew N (1997) Ineffectiveness of neurokinin-1 receptor antagonist in acute migraine: a crossover study. Cephalalgia 17:785-790.

Hanesch U, Pfrommer U, Grubb B, Heppelmann B, Schaible H (1993) The proportion of CGRP-immunoreactive and SP mRNA-containing dorsal root ganglion cells is increased by a unilateral inflammation of the ankle joint of the rat. Regul Pept 46:202-203.

Heath MJ, Womack M, MacDermott A (1994) Substance P elevates intracellular calcium in both neurons and glial cells from the dorsal horn of the spinal cord. J Neurophysiol 72:1192-1198.

Hirota N, Kuraishi Y, Hino Y, Sato Y, Satoh M, Takagi H (1985) Met-enkephalin and morphine but not dynorphin inhibit noxious stimuli-induced release of substance $\mathrm{P}$ from rabbit dorsal horn in situ. Neuropharmacology 24:567-570.

Hökfelt T, Kellerth J, Nilsson G, Pernow B (1975) Substance P: localization in the central nervous system and in some primary sensory neurons. Science 190:889-890.

Hsu S, Raine L, Fanger H (1981) The use of antiavidin antibody and avidin-biotin-peroxidase complex in immunoperoxidase technics. J Clin Pathol 75:816-821.

Hylden J, Wilcox G (1981) Intrathecal substance P elicits a caudallydirected biting and scratching behavior in mice. Brain Res 217:212-215.

Jasmin L, Wang H, Tarczy-Hornoch K, Levine JD, Basbaum AI (1994) Differential effects of morphine on noxious stimulus-evoked fos-like immunoreactivity in subpopulations of spinoparabrachial neurons. J Neurosci 14:7252-7260.

Jessell T, Iversen L (1977) Opiate analgesics inhibit substance P release from rat trigeminal nucleus. Nature 268:549-551. 
Jones S, Sedivec M, Light A (1990) Effects of iontophoresed opioids on physiologically characterized laminae I and II dorsal horn neurons in the cat spinal cord. Brain Res 532:160-174.

Kayser V, Guilbaud G (1983) The analgesic effects of morphine, but not those of the enkephalinase inhibitor thiorphan, are enhanced in arthritic rats. Brain Res 267:131-138.

Kiyama H, Morita Y, Noguchi K, Nakanishi S, Shiotani Y, Tohyama M (1988) Demonstration of rat preprotachykinin A mRNA in the rat trigeminal ganglion. J Chem Neuroanat 1:125-232.

Kuraishi Y, Hirota N, Sugimoto M, Satoh M, Takagi H (1983) Effects of morphine on noxious stimuli-induced release of substance $\mathrm{P}$ from rabbit dorsal horn in vivo. Life Sci 33:693-696.

Lang CW, Duggan AW, Hope PJ (1991) Analgesic doses of morphine do not reduce noxious stimulus-evoked release of immunoreactive neurokinins in the dorsal horn of the spinal cat. Br J Pharmacol 103:1871-1876.

Liu H, Mantyh P, Basbaum A (1997) NMDA-receptor regulation of substance $P$ release from primary afferent nociceptors. Nature 386:721-724.

Maggi CA, Schwartz TW (1997) The dual nature of the tachykinin NK1 receptor. Trends Pharmacol Sci 18:351-355.

Magnuson D, Dickenson A (1991) Lamina-specific effects of morphine and naloxone in dorsal horn of rat spinal cord in vitro. J Neurophysiol 66:1941-1950.

Mansour A, Fox C, Burke S, Meng F, Thompson R, Akil H, Watson S (1994) Mu, delta, and kappa opioid receptor mRNA expression in the rat CNS: an in situ hybridization study. J Comp Neurol 350:421-438.

Mantyh PW, DeMaster E, Malhotra A, Ghilardi JR, Rogers SD, Mantyh CR, Liu H, Basbaum AI, Vigna SR, Maggio JE, Simone DA (1995) Receptor endocytosis and dendrite reshaping in spinal neurons after somatosensory stimulation. Science 268:1629-1632.

Mapp P, Terenghi G, Walsh D, Chen S, Cruwys S, Garrett N, Kidd B, Polak J, Blake D (1993) Monoarthritis in the rat knee induces bilateral and time-dependent changes in substance $\mathrm{P}$ and calcitonin generelated peptide immunoreactivity in the spinal cord. Neuroscience 57:1091-1096.

Marvizon J, Martinez V, Grady E, Bunnett N, Mayer E (1997) Neurokinin 1 receptor internalization in spinal cord slices induced by dorsal root stimulation is mediated by NMDA receptors. J Neurosci 17:8129-8136.

Marvizon J, Grady E, Stefani E, Bunnett N, Mayer E (1999) Substance $P$ release in the dorsal horn assessed by receptor internalization: NMDA receptors counteract a tonic inhibition by GABA(B)receptors. Eur J Neurosci 11:417-426.

Mauborgne A, Lutz O, Legrand J, Hamon M, Cesselin F (1987) Opposite effects of delta and mu opioid receptor agonists on the in vitro release of substance P-like material from the rat spinal cord. J Neurochem 48:529-537.

Miaskowski C, Sutters K, Taiwo Y, Levine J (1991) Comparison of the antinociceptive and motor effects of intrathecal opioid agonists in the rat. Brain Res 553:105-109.

Minami M, Maekawa K, Yabuuchi K, Satoh M (1995) Double in situ hybridization study on coexistence of mu, delta and kappa opioid receptor mRNAs with preprotachykinin A mRNA in the rat dorsal root ganglia. Mol Brain Res 30:203-210.

Neumann S, Doubell T, Leslie T, Woolf C (1996) Inflammatory pain hypersensitivity mediated by phenotypic switch in myelinated primary sensory neurons. Nature 384:360-364.

Riley R, Loo C, Mantyh P, Basbaum A (1997) GABA-B but not GABA-A receptors inhibit noxious stimulus-evoked internalization of the neurokinin-1 (NK-1) receptor in rat spinal cord. Soc Neurosci Abstr 23:447.

Schafer M, Nohr D, Krause J, Weihe E (1993) Inflammation-induced upregulation of NK1 receptor mRNA in dorsal horn neurons. NeuroReport 4:1007-1010.

Suarez-Roca H, Maixner W (1993) Activation of kappa opioid receptors by $\mathrm{U} 50488 \mathrm{H}$ and morphine enhances the release of substance $\mathrm{P}$ from rat trigeminal nucleus slices. J Pharmacol Exp Ther 264:648-653.

Teoh H, Malcangio M, Bowery N (1996) GABA, glutamate and substance P-like immunoreactivity release: effects of novel GABAB antagonists. Br J Pharmacol 118:1153-1160.

Vigna SR, Bowden JJ, McDonald DM, Fisher J, Okamoto A, McVey DC, Payan DG, Bunnett NW (1994) Characteriztion of antibodies to the rat substance $\mathrm{P}(\mathrm{NK}-1)$ receptor and to a chimeric substance $\mathrm{P}$ receptor expressed in mammalian cells. J Neurosci 14:834-845.

Willcockson W, Kim J, Shin H, Chung J, Willis W (1986) Actions of opioids on primate spinothalamic tract neurons. J Neurosci 6:2509-2520.

Woolf C, Fitzgerald M (1981) Lamina-specific alteration of c-fibre evoked activity by morphine in the dorsal horn of the rat spinal cord. Neurosci Lett 25:37-41.

Yaksh T, Jessell T, Gamse R, Mudge A, Leeman S (1980) Intrathecal morphine inhibits substance $\mathrm{P}$ releases from mammalian spinal cord in vivo. Nature 286:155-157.

Yu A, Hertz E, Hertz L (1984) Alterations in uptake and release rates for GABA, glutamate, and glutamine during biochemical maturation of highly purified cultures of cerebral cortical neurons, a GABAergic preparation. J Neurochem 42:951-959.

Zachariou V, Goldstein B (1996a) Delta-opioid receptor modulation of the release of substance P-like immunoreactivity in the dorsal horn of the rat following mechanical or thermal noxious stimulation. Brain Res 736:305-314.

Zachariou V, Goldstein B (1996b) Kappa-opioid receptor modulation of the release of substance $\mathrm{P}$ in the dorsal horn. Brain Res 706:80-88.

Zhang X, Bao L, Arvidsson U, Elde R, Hökfelt T (1998) Localization and regulation of the delta-opioid receptor in dorsal root ganglia and spinal cord of the rat and monkey: evidence for association with the membrane of large dense-core vesicles. Neuroscience 82:1225-1242. 